\title{
STRATEGI PENDIDIKAN KARAKTER PADA MADRASAH TSANAWIYAH MUHAMMADIYAH 01 PURBALINGGA, JAWA TENGAH
}

\author{
Umi Muzayanah \\ Peneliti Balai Litbang Agama Semarang \\ Jl. Untung Suropati Kav.70 Bambankerep Ngaliyan Semarang \\ Email: umimoza78@gmail.com
}

\begin{abstract}
This study aimed to describe the strategy of integrated character education in madrasah management. This research is a case study done in MTs Muhammadiyah 01 Purbalingga, Central Java, by using descriptive qualitative approach. Data collection was done by interview, observation, and document review. The results showed that (1) strategy of character education through madrasah management has not been implemented to the fullest. In the preparation of planning activities not listed explicitly madrasah character values to be achieved, both in the work plan of the madrasah (RKM) annual and mid-term (four years). In practical terms, this madrasah has internalized the values of character through discipline and self habituation activities; (2) integrated character education strategy in the implementation of learning can be seen in subjects of science, Civics, sosial studies, Quran Hadit, and morals. Internalization of character values is applied to the planning, implementation of learning, through the process of evaluation of learning outcomes; and (3) the strategy of character education through training activities is conducted through extracurricular activities such as scouting, PMR (Youth Red Cross), Pencak Silat Tapak Suci, sports, training for girls, and so forth.
\end{abstract}

Keywords: strategy, character education, madrasah tsanawiyah

\begin{abstract}
Abstrak
Penelitian ini bertujuan untuk mendeskripsikan strategi pendidikan karakter yang terintegrasi pada manajemen madrasah. Penelitian ini merupakan penelitian kasus di MTs Muhammadiyah 01 Purbalingga, Jawa Tengah, dengan menggunakan pendekatan kualitatif deskriptif. Instrumen pengumpulan data menggunakan teknik wawancara, observasi, dan kajian dokumen. Hasil penelitian menunjukan bahwa (1) strategi pendidikan karakter melalui manajemen madrasah belum diterapkan secara maksimal. Dalam penyusunan perencanaan kegiatan madrasah belum tercantum secara eksplisit nilai-nilai karakter yang akan dicapai, baik pada rencana kerja madrasah (RKM) tahunan maupun jangka menengah (empat tahunan). Pada tataran praktis, madrasah ini sudah melakukan internalisasi nilai-nilai karakter melalui tata tertib dan kegiatan pembiasaan diri; (2) strategi pendidikan karakter terintegrasi dalam pelaksanaan pembelajaran sudah nampak pada mata pelajaran IPA (Ilmu Pengetahun Alam), PKn (Pendidikan Kewarganegaraan), IPS (Ilmu Pengetahuan Sosial), Quran Hadit, dan Akidah Akhlak. Internalisasi nilai-nilai karakter diterapkan pada proses perencanaan, pelaksanaan pembelajaran, sampai proses evaluasi hasil belajar; dan (3) strategi pendidikan karakter melalui kegiatan pembinaan dilakukan melalui kegiatan ekstrakurikuler pramuka, PMR (Palang Merah Remaja), kegiatan pencak silat Tapak Suci, olah raga, dan keputrian, dan sebagainya.
\end{abstract}

Kata kunci: strategi, pendidikan karakter, madrasah tsanawiyah

Naskah diterima 25 Oktober 2014. Revisi pertama, 11 November 2014. Revisi kedua, 19 November 2014 dan revisi terakhir 3 Desember 2014. 


\section{PENDAHULUAN}

Fungsi pendidikan nasional adalah mengembangkan dan membentuk watak serta peradaban bangsa yang bermartabat dalam rangka mencerdaskan kehidupan bangsa. Tujuan pendidikan nasional untuk mengembangkan potensi siswa agar menjadi manusia yang beriman dan bertakwa kepada Tuhan Yang Maha Esa, berakhlak mulia, sehat, berilmu, cakap, kreatif, mandiri, dan menjadi warga negara yang demokratis serta bertanggungjawab. Fungsi dan tujuan pendidikan nasional menunjukan pentingnya pembentukan karakter siswa sejak dini.

Pembentukan karakter sejak dini sangatlah penting untuk mengembangkan karakter positif bagi anak. Perkembangan karakter positif yang terhambat akan berakibat pada terjadinya kenakalan yang berujung pada tindakan kriminal di kalangan pelajar. Data yang tercatat pada Komisi Nasional Perlindungan Anak (Komnas PA) sedikitnya terjadi 2.008 kasus kriminalitas yang dilakukan anak usia sekolah pada kuartal pertama tahun 2012. Kasus kriminalitas itu meliputi berbagai jenis kejahatan seperti pencurian, tawuran, dan pelecehan seksual yang dilakukan siswa SD hingga SMA. Angka kriminalitas yang dilakukan oleh anak usia sekolah cenderung meningkat dari tahun ke tahun, dengan data 3 tahun terakhir tercatat tahun 2010 terjadi sebanyak 2.413 kasus dan tahun 2011 sebanyak 2.508 kasus kriminalitas anak. ${ }^{1}$ Data tersebut mengindikasikan adanya dekadensi moral pada kalangan pelajar yang sangat memprihatinkan. Hal ini menjadi tantangan besar bagi pemerintah, guru dan orang tua untuk lebih memperhatikan dan meningkatkan pendidikan karakter bagi peserta didik, baik pendidikan karakter yang dikembangkan di

${ }^{1}$ Afrianti, Desy dan Siti Ruqoyah. 2012. 2.008 Kasus Kriminal Dilakukan Anak-anak. Diperoleh melalui http:// metro.news.viva.co.id/news/read/312779-2-008-kasuskriminal-dilakukan-anak-anak. Diakses tanggal 22 April 2013. lingkungan keluarga, sekolah, maupun di lingkungan masyarakat.

Pendidikan karakter di sekolah adalah upaya yang terencana untuk memfasilitasi peserta didik mengenal, peduli, dan menginternalisasi nilai-nilai karakter secara terintegrasi melalui kegiatan sekolah. Integrasi pendidikan karakter di sekolah dapat dilakukan melalui beberapa upaya, yaitu (1) pendidikan karakter secara terintegrasi dalam proses pembelajaran; (2) pendidikan karakter secara terintegrasi melalui manajemen/ pengelolaan sekolah; dan (3) pendidikan karakter melalui kegiatan pembinaan siswa. Sasaran utama pendidikan karakter adalah seluruh peserta didik. Namun demikian warga sekolah lainnya seperti tenaga pendidik dan tenaga kependidikan harus menjadi model dalam mengembangkan karakter masingmasing.

Pendidikan karakter yang terintegrasi dalam proses pembelajaran diimplementasikan dalam pembelajaran mata pelajaran-mata pelajaran yang terkait, seperti Agama, PKn, IPS, IPA, Penjas Orkes, dan lainnya. Hal ini dimulai dengan pengenalan nilai secara kognitif, penghayatan nilai secara afektif, akhirnya ke pengamalan nilai secara nyata oleh peserta didik dalam kehidupan sehari-hari. Integrasi pendidikan karakter melalui manajemen sekolah diimplementasikan dalam aktivitas manajemen sekolah, seperti pengelolaan siswa, regulasi/peraturan sekolah, sumber daya manusia, sarana dan prasarana, keuangan, perpustakaan, pembelajaran, penilaian, dan informasi, serta pengelolaan lainnya. Sedangkan integrasi pendidikan karakter melalui kegiatan pembinaan kepesertadidikan dapat dilakukan dengan internalisasi nilainilai karakter pada kegiatan-kegiatan olah raga, seni budaya, keagamaan, kepramukaan, kesehatan, latihan dasar kepemimpinan, dan kegiatan lainnya.

Pembentukan nilai-nilai karakter pada usia remaja sangat penting dalam upaya menangkal pengaruh negatif yang dapat 
merusak karakter remaja sebagai generasi bangsa. Oleh karena itu SMP sebagai salah satu jenjang pada lembaga pendidikan formal sebagai wadah resmi pembinaan generasi muda diharapkan dapat meningkatkan peranannya dalam pembentukan kepribadian peserta didik melalui peningkatan intensitas dan kualitas pendidikan karakter.

Madrasah Tsanawiyah (MTs) merupakan jenjang dasar pada pendidikan formal di Indonesia, setara dengan sekolah menengah pertama (SMP), yang pengelolaannya dilakukan oleh Kementerian Agama. Madrasah Tsanawiyah menghadapi tantangan yang sama dengan sekolah umum pada level sekolah menengah pertama lainnya dalam pembentukan karakter peserta didik. Sebagai lembaga pendidikan yang berbasis religi, pelaksanaan pendidikan pada madrasah tsanawiyah memiliki tambahan mata pelajaran yang bermuatan religi lebih banyak dibandingkan dengan sekolah umum lainnya. Diantara mata pelajaran agama yang diajarkan di madrasah tsanawiyah adalah Aqidah Akhlak, Fiqih, Al-Quran Hadits, Bahasa Arab, dan Sejarah Kebudayaan Islam, yang masing-masing memiliki alokasi waktu sendiri untuk setiap minggunya. Dengan penambahan mata pelajaran bermuatan religi diharapkan dapat berimplikasi positif terhadap perkembangan karakter peserta didik pada madrasah. Berdasarkan latar belakang penelitian yang telah dikemukakan, maka dapat dirumuskan permasalahan penelitian sebagai berikut.

1. Bagaimana strategi pendidikan karakter yang terintegrasi dalam proses pembelajaran pada MTs Muhammadiyah 01 Purbalingga?

2. Bagaimana strategi pendidikan karakter yang terintegrasi dalam manajemen sekolah pada MTs Muhammadiyah 01 Purbalingga?

3. Bagaimana strategi pendidikan karakter yang terintegrasi melalui kegiatan pem- binaan siswa pada MTs Muhammadiyah 01 Purbalingga?

Penelitian ini bertujuan untuk mendeskripsikan strategi pendidikan karakter melalui proses pembelajaran, manajemen madrasah, dan kegiatan pembinaan siswa pada MTs Muhammadiyah 01 Purbalingga. Secara teoretik, penelitian ini diharapkan bermanfaat dalam memberikan informasi dan kecukupan referensi tentang kajian pendidikan karakter pada satuan pendidikan, khususnya pada madrasah tsanawiyah. Sedangkan secara praktis, hasil penelitian ini diharapkan dapat bermanfaat bagi madrasah dalam mengembangkan nilai-nilai karakter peserta didik mulai dari proses perencanaan madrasah, kegiatan pembelajaran, sampai pada kegiatan pembinaan kepesertadidikan. Hasil penelitian juga diharpkan bermanfaat bagi kepala madrasah sebagai referensi ilmiah tentang strategi pendidikan karakter di madrasah, yang selanjutnya dapat dijadikan rujukan dalam mengambil kebijakan terkait dengan implementasi pendidikan karakter di madrasah

\section{Kerangka Teoretik}

\section{Pendidikan Karakter}

Karakter identik dengan akhlak, sehingga karakter merupakan nilai-nilai perilaku manusia yang universal yang meliputi seluruh aktivitas manusia, baik dalam hubungannya dengan Tuhan, dengan sesama manusia, dengan lingkungan, maupun hubungan dengan dirinya sendiri. Hubungan ini terwujud dalam dalam pikiran, sikap, perasaan, perkataan, dan perbuatan berdasarkan norma-norma agama, hukum, tata krama, budaya, dan adat istiadat. ${ }^{2}$

${ }^{2}$ Marzuki. 2011. Integrasi Pendidikan Karakter dalam Pembelajaran di Sekolah Menengah Pertama. Makalah Seminar "Internalisasi Pendidikan Karakter Melalui Proses Pembelajaran dalam rangka Mewujudkan Generasi yang Bernurani, Cendekia, dan Mandiri” yang 
KaraktermenurutAlwisol diartikansebagai gambaran tingkah laku yang menonjolkan nilai benar-salah, baik-buruk, baik secara eksplisit maupun implisit. ${ }^{3}$ Sedangkan Lickona menjelaskan bahwa karakter terdiri dari tiga hal yaitu moral knowing, moral feeling, dan moral behavior. Karakter mulia (good character) meliputi pengetahuan tentang kebaikan, lalu menimbulkan komitmen (niat) terhadap kebaikan, danakhirnyabenar-benar melakukan kebaikan. Dengan kata lain, karakter mengacu kepada serangkaian pengetahuan (cognitives), sikap (attitudes), dan motivasi (motivations), serta perilaku (behaviors) dan keterampilan (skills). ${ }^{4}$

Pendidikan karakter adalah segala sesuatu yang dilakukan guru, yang mampu mempengaruhi karakter peserta didik. Guru membantu membentuk watak peserta didik. Hal ini mencakup keteladanan bagaimana perilaku guru, cara guru berbicara atau menyampaikan materi, bagaimana guru bertoleransi, dan berbagai hal terkait lainnya. ${ }^{5}$ Pendidikan karakter merupakan pendidikan nilai, pendidikan budi pekerti, pendidikan moral, pendidikan watak yang bertujuan mengembangkan kemampuan peserta didik untuk memberikan keputusan baik-buruk, memelihara apa yang baik \& mewujudkan kebaikan itu dalam kehidupan sehari-hari dengan sepenuh hati. ${ }^{6}$

Fungsi utama dari pendidikan karakter adalah (1) pengembangan potensi siswa; (2) perbaikan; dan (3) sebagai penyaring budaya bangsa sendiri dan budaya bangsa lain yang

diselenggarakan di SMP Negeri 5 Wates pada hari Senin, 25 Juli 2011. h.3. h.8.

${ }^{3}$ Alwisol. 2006. Psikologi Kepribadian. Malang: UMM.

${ }^{4}$ Lickona, T. 1991. Educating for Character: How Our School Can Teach Respect and Responsibility. New York, Toronto, London, Sydney, Aucland: Bantam books. h.51

${ }^{5}$ Kementerian Pendidikan Nasional. 2010. Pendidikan Karakter Di Sekolah Menengah Pertama. Jakarta. h.13.

${ }^{6}$ Pusat Kurikulum dan Perbukuan Badan Penelitian dan Pengembangan Kementerian Pendidikan Nasional. 2011. Pedoman Pelaksanaan Pendidikan Karakter. Berdasarkan Pengalaman di Satuan Pendidikan Rintisan. Jakarta. h.1. tidak sesuai dengan nilai-nilai budaya dan karakter bangsa yang bermartabat.' Tujuan pendidikan karakter adalah membentuk bangsa yang tangguh, kompetitif, berakhlak mulia, bermoral, bertoleran, bergotong royong, berjiwa patriotik, berkembang dinamis, berorientasi ilmu pengetahuan dan teknologi yang semuanya dijiwai oleh iman dan takwa kepada Tuhan yang Maha Esa berdasarkan Pancasila. ${ }^{8}$

Pendidikan karakter di Indonesia mulai diluncurkan pada tahun 2010 oleh Presiden Susilo Bambang Yudhoyono bertepatan dengan peringatan hari Pendidikan Nasional. Implementasi pendidikan karakter di sekolah diterapkan dalam pembelajaran mulai jenjang pendidikan usia dini/TK, SD, SMP, SMA, dan Perguruan tinggi. Nilai-nilai karakter yang dapat dijadikan sekolah sebagai nilai-nilai utama yang diambil/disarikan dari butirbutir SKL dan mata pelajaran-mata pelajaran SMP yang ditargetkan untuk diinternalisasi oleh siswa adalah (1) religius; (2) jujur; (3) bertanggungjawab; (4) bergaya hidup sehat; (5) disiplin; (6) kerja keras; (7) percaya diri; (8) berjiwa wirausaha; (9) kreatif; (10) mandiri; (11) ingin tahu; (12) cinta ilmu; (13) sadar akan hak dan kewajiban diri dan orang lain; (14) patuh pada aturan-aturan sosial; (15) menghargai karya dan prestasi orang lain; (16) santun; (17) demokratis; (18) peduli sosial dan lingkungan; (19) nasionalis; dan (20) menghargai keberagaman. ${ }^{9}$

\section{Pembelajaran}

Pembelajaran dalam arti sempit diartikan sebagai suatu proses atau cara yang dilakukan agar seseorang dapat melakukan kegiatan belajar. Sedangkan dalam arti luas

\footnotetext{
7 Sulistyowati, E. 2012. Implementasi Kurikulum Pendidikan Karakter. Yogyakarta: PT. Citra Aji Parama. h.27.

${ }^{8}$ Pusat Kurikulum dan Perbukuan Badan Penelitian dan Pengembangan Kementerian Pendidikan Nasional. op.cit, h.2.

${ }^{9}$ Kementerian Pendidikan Nasional. op.cit., h.16-19.
} 
pembelajaran berarti suatu proses atau kegiatan yang sistematis, yang bersifat interaktif dan komunikatif antara guru sebagai pendidik dengan peserta didik, sumber belajar, dan lingkungan. Dalam proses pembelajaran guru akan mengatur seluruh rangkaian kegiatan pembelajaran, mulai dari membuat desain pembelajaran, melaksanakan kegiatan pembelajaran, bertindak mengajar atau membelajarkan, melakukan evaluasi pembelajaran..$^{10}$ Pendidikan karakter secara terintegrasi di dalam proses pembelajaran adalah pengenalan nilai-nilai, fasilitasi diperolehnya kesadaran akan pentingnya nilai-nilai, dan penginternalisasian nilai-nilai ke dalam tingkah laku peserta didik seharihari melalui proses pembelajaran baik yang berlangsung di dalam maupun di luar kelas pada semua mata pelajaran. Dengan demikian, kegiatan pembelajaran, selainuntukmenjadikan peserta didik menguasai kompetensi (materi) yang ditargetkan, juga dirancang dan dilakukan untuk menjadikan peserta didik mengenal, menyadari/peduli, dan menginternalisasi nilai-nilai dan menjadikannya perilaku. ${ }^{11}$ Pelaksanaan pendidikan karakter secara terpadu dalam proses pembelajaran adalah melalui internalisasi pendidikan karakter pada semua mata pelajaran. Tujuannya adalah untuk memperkenalkan nilai-nilai pendidikan karakter di setiap mata pelajaran. Menurut Sulistyowati strategi pendidikan karakter secara terpadu pada proses pelaksanaan pembelajaran meliputi kegiatan pendahuluan, kegiatan inti, dan kegiatan penutup. Metode pembelajaran berwawasan karakter dapat menggunakan berbagai pendekatan, diantaranya adalah pendekatan kontekstual (Contextual Teaching And Learning) sebagai konsep belajar dan mengajar yang membantu guru dan siswa mengaitkan antara materi yang diajarkan dengan situasi dunia nyata. Pembelajaran berbasis kontekstual melibatkan

${ }^{10}$ Arifin, Zainal. 2011. Evaluasi Pembelajaran: Prinsip, Teknik, Prosedur. Bandung: PT. Remaja Rosdakarya. h.1012.

${ }^{11}$ Kementerian Pendidikan Nasional. op.cit., h.34. tujuh komponen utama pembelajaran produktif, yakni konstruktivisme (constructivism), bertanya (questioning), menemukan (inquiry), masyarakat belajar (learning community), pemodelan (modeling), refleksi (reflection), dan penilaian sebenarnya (authentic assessment). ${ }^{12}$

\section{Manajemen}

Manajemen berasal dari kata kerja to manage (bahasa Inggris) yang artinya mengurus, mengatur, melaksanakan, dan mengelola. ${ }^{13}$ Menurut Fathurrohman manajemen diartikan sebagai proses yang membedabedakan atas perencanaan, pengorganisasian, penggerakan pelaksanaan dan pengendalian, dengan memanfaatkan ilmu dan seni, agar tujuan yang telah ditetapkan dapat tercapai. ${ }^{14}$ Usman mendefiniskan manajemen sebagai proses perencanaan, pengorganisasian, pengarahan, dan pengendalian sumber daya organisasi untuk mencapai tujuan secara efektif dan efisien. Dalam dunia pendidikan, manajemen pendidikan didefiniskan sebagai proses perencanaan, pengorganisasian, pengarahan, dan pengendalian sumber daya pendidikan untuk mencapai tujuan pendidikan secara efektif, efisien, mandiri, dan akuntabel. ${ }^{15}$

Pendidikan karakter melalui manajemen sekolah adalah pengenalan nilai-nilai, fasilitasi diperolehnya kesadaran akan pentingnya nilai-nilai, dan penginternalisasian nilai-nilai ke dalam tingkah laku peserta didik sehari-hari melalui pelaksanaan manajemen sekolah yang berkarakter baik. Beberapa contoh bentuk kegiatan pendidikan karakter yang terpadu dengan manajemen sekolah antara lain: (a) pelanggaran tata tertib yang berimplikasi pada pengurangan nilai dan hukuman/ pembinaan,

\footnotetext{
${ }^{12}$ Sulistyowati, E, op.cit., h.128-171.

${ }^{13}$ Gomes, F. 2003. Manajemen Sumber Daya Manusia. Yogyakarta: Andi Offset. h.1.

${ }^{14}$ Fathurrohman, P., Suryana, AA, dan Fatriany, F. 2013. Pengembangan Pendidikan Karakter. Bandung: Refika Aditama. h.149-150.

${ }^{15}$ Usman, H. 2009. Manajemen. Teori, Praktik, dan Riset Pendidikan. Jakarta: Bumi Aksara. h.5-12.
} 
(b) penyediaan tempat-tempat pembuangan sampah, (c) penyelenggaraan kantin kejujuran, (d) penyediaan kotak saran, (d) penyediaan sarana ibadah dan pelaksanaan ibadah, misalnya: shalat dhuhur berjamaah, (e) Salimtaklim (jabat tangan) setiap pagi saat siswa memasuki gerbang sekolah, (f) pengelolaan \& kebersihan ruang kelas oleh siswa, dan bentukbentuk kegiatan lainnya. ${ }^{16}$

\section{Kegiatan Pembinaan}

Kegiatan pembinaan peserta didik adalah kegiatan pendidikan di luar mata pelajaran dan pelayanan konseling untuk membantu pengembangan peserta didik sesuai dengan kebutuhan, potensi, bakat, dan minat mereka melalui kegiatan yang secara khusus diselenggarakan oleh pendidik dan atau tenaga kependidikan yang berkemampuan dan berkewenangan di sekolah. Adapun tujuan kegiatan pembinaan kesiswaan adalah sesuai dengan yang tercantum dalam Permendiknas No. 39 Tahun 2008, yaitu:

1. Mengembangkan potensi siswa secara optimal dan terpadu yang meliputi bakat, minat dan kretivitas;

2. Memantapkan kepribadian siswa untuk mewujudkan ketahanan sekolah sebagai lingkungan pendidikan sehingga terhindar dari usaha dan pengaruh negatif dan bertentangan dengan tujuan pendidikan;

3. Mengaktualisasikan potensi siswa dalam pencapaian prestasi unggulan sesuai bakat dan minat;

4. Menyiapkan siswa agar menjadi warga masyarakat yang berakhlak mulia, demokratis, menghormati hak-hak asasi manusia dalam rangka mewujudkan masyarakat madani. ${ }^{17}$

Pembentukan karakter dalam kegiatan pembinaan peserta didik dapat dilihat dari visi

${ }^{16}$ Kementerian Pendidikan Nasional, op.cit., h.26.

${ }^{17}$ Kementerian Pendidikan Nasional, op.cit. 27-95. dan misi kegiatan pembinaan peserta didik itu sendiri. Visi kegiatan pembinaan peserta didik adalah berkembangnya potensi, bakat dan minat secara optimal, serta tumbuhnya kemandirian dan kebahagiaan peserta didik yang berguna untuk diri sendiri, keluarga dan masyarakat. Misi kegiatan pembinaan peserta didik adalah (1) menyediakan sejumlah kegiatan yang dapat dipilih oleh peserta didik sesuai dengan kebutuhan, potensi, bakat, dan minat mereka; (2) menyelenggarakan kegiatan yang memberikan kesempatan peserta didik mengeskpresikan diri secara bebas melalui kegiatan mandiri dan atau kelompok. Kegiatan peserta didik dapat diberikan melalui kegiatan ekstrakurikuler dan pengembangan diri berupa pembiasaan atau pembudayaan. Melalui kegiatan ekstrakurikuler diharapkan dapat mengembangkan kemampuan dan rasa tanggung jawab sosial, serta potensi dan prestasi peserta didik. ${ }^{18}$

\section{Metodologi Penelitian}

Penelitian ini menggunakan pendekatan kualitatif deskriptif dengan metode studi kasus. Pengumpulan data dilakukan melalui studi dokumentasi, wawancara, dan observasi. Studi dokumentasi dilakukan untuk memperoleh data tentang profil madrasah, program kerja madrasah, peraturan/tata tertib bagi peserta didik, daftar poin pelanggaran terhadap tata tertib madrasah, jenis kegiatan pembinaan peserta didik, dan dokumen lain yang terkait dengan fokus penelitian. Wawancara dilakukan untuk menggali data tentang implementasi pendidikan karakter yang telah diterapkan di madrasah, dengan sasaran interviewee adalah kepala madrasah, guru, tenaga kependidikan, dan beberapa peserta didik. Sedangkan observasi dilakukan untuk memperoleh data secara langsung terkait dengan pelaksanaan pendidikan karakter pada madrasah, baik yang terintegrasi melalui manajemen sekolah,

\footnotetext{
${ }^{18}$ Sulistyowati, E, op.cit., 135-136.
} 
kegiatan pembinaan peserta didik, maupun proses pembelajaran.

Sasaran penelitian ini MTs Muhammadiyah 01 Purbalingga, yang terletak di pusat kota Purbalingga, dengan sumber data adalah kepala madrasah, tenaga pendidik dan tenaga kependidikan, peserta didik, dan dokumendokumen yang relevan dengan fokus penelitian. Penelitian ini dilakukan selama 3 bulan, mulai bulan Agustus sampai Oktober 2013.

Analisis data yang digunakan dalam penelitian ini adalah dengan membuat catatan lapangan (field note) selama proses pengumpulan data di lapangan, yang terdiri dari catatan hasil wawancara dan catatan observasi. Selanjutnya membaca kembali seluruh teks yang ada pada catatan lapangan dan membuat ringkasan serta menghilangkan duplikasiduplikasi. Ringkasan yang telah dibuat kemudian dilakukan klasifikasi data (coding) yang akan menghasilkan pola-pola umum dan dikelompokkan berdasarkan fokus/kajian. Selanjutnya dilakukan analisis terhadap hasil klasifikasi yang dikaitkan dengan teori-teori yang relevan.

\section{HASIL DAN PEMBAHASAN}

\section{Manajemen Madrasah}

Manajemen madrasah yang diterapkan pada MTs Muhammadiyah 01 Purbalingga meliputi proses perencanaan, pelaksanaan, dan pengendalian. Proses perencanaan dilakukan dengan menyusun Rencana Kerja Madrasah (RKM) dan Rencana Kerja dan Anggaran Madrasah (RKAM). RKM yang disusun meliptu RKM jangka pendek (satu tahunan) dan RKM jangka menengah (4 tahunan). Penyusunan RKM didasarkan pada kondisi real madrasah, meliputi kondisi sarana prasarana, potensi sumber daya manusia yang dimiliki, dan tantangan yang dihadapi baik dari dalam maupun dari luar madrasah.

Pelaksanaan manajemen madrasah diterapkan melalui beberapa kebijakan, baik kebijakan yang mengikat guru maupun kebijakan yang mengikat peserta didik. Kebijakaan yang mengikat guru berupa tata tertib yang tidak tertulis, diantaranya adalah kedisiplinan terhadap jam mengajar guru yang harus dipenuhi sesuai dengan jadwal yang telah ditentukan. Apabila berhalangan hadir, guru wajib membuat surat ijin dan mengganti kehadirannya dengan memberikan tugas kepada peserta didik. Meski tata tertib sudah terealisasi, namun belum ada sanksi yang ditetapkan oleh pihak madrasah terkait dengan pelanggaran tata tertib yang dilakukan oleh guru. Kebijakan madrasah yang mengikat peserta didik berupa tata tertib dan kegiatan pembiasaan diri. Tata tertib yang dibuat untuk peserta didik diikuti oleh adanya sanksi berupa poin pelanggaran terhadap peserta didik yang tidak mematuhi tata tertib yang sudah dibuat oleh pihak madrasah.

Pengendalian sebagai bagian tidak terpisahkan dari sebuah proses manajemen dilakukan melalui pengawasan oleh kepala madrasah dibantu dengan guru Bimbingan Konseling (BK) dan guru wali kelas. Pengendalian dilakukan terhadap seluruh kegiatan di lingkungan madrasah. Kegiatan di dalam kelas yang diawasi oleh guru dan wali kelas, sedangkan kegiatan di luar kelas menjadi tanggungjawab bersama antara guru, kepala madrasah, dan guru BK.

MTs Muhammaidyah 01 Purbalingga sebagai lembaga pendidikan yang berbasis religi mengedepankan nilai religi dan disiplin dalam seluruh kegiatan di lingkungan madrasah. Nilai-nilai religi dan disiplin diterapkan dalam bentuk kebijakan madrasah sebagai bagian dari manajemen madrasah. Kebijakan madrasah terkait dengan penanaman nilai-nilai religi dan kedisiplinan bagi peserta didik dilakukan melalui beberapa kegiatan pembiasaan diri yang wajib dipatuhi oleh setiap peserta didik. Kegiatan pembiasaan diri tersebut diantaranya adalah:

1. Sholat dzuhur berjamaah bagi seluruh peserta didik yang masuk pada rombel 
pagi. Karena keterbatasan kapasitas/ daya tampung masjid yang terletak dalam komplek madrasah, maka sholat dzuur berjamaah bagi kelas IX dilakukan di masjid agung.

2. Sholat ashar berjamaah bagi peserta didik yang masuk pada kegiatan belajar mengajar siang hari.

3. Sholat dhuha yang dilakukan dengan bergiliran karena keterbatasan daya tampung masjid. Sholat dhuha dibimbing langsung oleh guru yang sedang mengajar saat giliran tiba. Bagi peserta didik kelas IX, mulai semester awal sudah diwajibkan melakukan sholat dhuha.

4. Sholat jumat wajib bagi peserta didik lakilaki dan dilakukan di masjid agung. Sholat jumat dilakukan setelah pembelajaran selesai dan sebelum pulang sekolah. Pihak madrasah juga membuat absen khusus bagi peserta didik laki-laki yang wajib ditandatangani setelah selesai sholat jumat.

5. Bagi peserta didik kelas IX yang akan menghadapi ujian nasional (UN), diwajibkan mengikuti mabid (bermalam) di sekolah. Kegiatan mabid dilakukan setiap malam minggu, yang berisi kegiatan belajar dan sholat tahajud bersama. Peserta didik dibagi menjadi 3 (tiga) kelompok berdasarkan tingkat reputasi akademik, yaitu kelompok dengan prestasi belajar tinggi, sedang, dan rendah. Kegiatan ini berlangsung menjelang pelaksanaan ujian akhir nasional, sampai 6 kali kegiatan, dimana 1 kali kegiatan dilaksanakan bersama motivator yang biasa didatangkan dari Universitas Muahmmadiyah Purwokerto (UMP), yang dilaksanakan pada hari minggu siang. Pada $\mathrm{H}-7$ sebelum pelaksanaan UN, kegiatan mabid disertai dengan sungkem kepada orang tua untuk meminta doa restu.
6. Pembagian piket untuk masing-masing kelas 2 (dua) orang setiap harinya. Petugas piket memiliki kewajiban untuk membeli kantong plastik untuk mengumpulkan sampah dan menaruh di tempat sampah yang disediakan di depan kelas.

7. Infak yang diwajibkan bagi peserta didik setiap hari Jumat dengan besaran infak tidak ditentukan. Uang yang diperoleh dari infak dikelola oleh OSIS dan digunakan untuk kegiatan-kegiatan yang tidak dibiayai oleh BOS, seperti konsumsi perpisahan, peringatan hari besar Islam, tali asih bagi peserta didik yang sakit, lomba-lomba, dan lain sebagainya.

8. Pemberian santunan bagi peserta didik yang mengalami musibah. Rincian pemberian santunan bagi peserta didik yaitu (1) opname Rp. 150.000,- (2) sakit di rumah sebesar Rp. 100.000,- (3) wali murid opname Rp. 100.000,- dan (4) takziah sebesar 150.000,-. Dana santunan berasal dari iuran kelas ditambah dengan dana kas yang bersumber dari infak.

Kegiatan pembiasaan diri sudah berjalan efektif dan dipatuhi oleh peserta didik baik kelas VII, VIII maupun kelas IX. Jika diketahui terdapat peserta diidk yang tidak melakukan sholat dzuhur/ashar berjamaah, maka peserta didik tersebut akan diantar ke masjid oleh guru BK dan ditunggui selama mengerjakan sholat. Khusus bagi peserta didik putri pihak madrasah telah membuat kartu haid (datang bulan), yang dibuat untuk menghindari adanya alasan tidak melakukan sholat berjamaah karena sedang datang bulan.

\section{Kegiatan Pembinaan}

Pelaksanaan kegiatan pembinaan bagi peserta didik pada MTS Muhammadiyah 01 Purbalingga dilakukan melalui penyelenggaraan ekstra kurikuler, meliputi: 
1. Kegiatan pramuka

Kegiatan pramuka dilaksanakan setiap hari jumat siang sampai sore hari. Kegiatan ini wajib diikuti oleh peserta didik kelas VII. Visi dari kegiatan pramuak adalah "memupuk jiwa cinta tanah air dan kepanduan".

2. Kegiatan tapak suci

Kegiatan tapak suci yang merupakan salah satu kegiatan bela diri dilaksanakan pada hari Selasa. Kegiatan ini diikuti oleh peserta didikyang memangberminat untuk mengikutinya. Visi kegiatan ini adalah "membina jiwa disiplin dan ketangkasan". Kegiatan tapak suci merupakan kegiatan ekstra kurikuler unggulan di madrasah ini yang banyak diminati oleh peserta didik, dan sudah sering memperoleh prestasi pada beberapa kali pertandingan.

\section{Kegiatan PMR}

Kegiatan PMR dilaksanakan seminggu sekali pada hari Selasa. Kegiatan ini hanya diikuti oleh peserta didik yang berminat saja dan tidak diwajibkan bagi seluruh peserta didik. Visi kegiatan ini adalah "melatih hidup sehat dan bersih".

4. Kegiatan TIK

Kegiatan TIK bersifat temporer, tidak mempunyai jadwal yang tetap. Kegiatan yang diikuti oleh peserta didik laki-laki dan perempuan ini fokus pada pengenalan hardware komputer. Visi kegiatan ini adalah "menyadarkan, memotivasi, mengembangkan kemampuan belajar mandiri, berinisiatif, inovatif, dan bertanggungjawab dalam penggunaan teknologi informasi dan komunikasi untuk pembelajaran, bekerja, dan pemecahan masalah sehari-hari".

5. Kegiatan olah raga

Kegiatan olah raga yang dilakukan dua minggu sekali ini maish sebatas pada olah raga sepak bola yang diikuti oleh peserta didik laki-laki yang berminat saja. Kegiatan ini meiliki visi "mengembangkan keterampilan pengelolaan diri dalam upaya pengembangan dan pemeliharaan kebugaran jasmani serta pola hidup sehat melalui berbagai aktifitas jasmani dan olah raga yang terpilih serta memahami teknik pelaksanaannya".

6. Kegiatan keputrian

Kegiatan kepurtian merupakan kegiatan ekstra kurikuler khusus bagi peserta didik perempuan. Kegiatan ini dilaksanakan setiap hari jumat pada saat peserta didik laki-laki melaksanakan sholat jumat di masjid. Kegiatan ini diwajibkan bagi peserta diidk kelas VII dan VIII. Materi yang diajarkan dan dipraktekan berbedabeda tiap kelas sesuai dengan undian yang didapatkan. Materi kegiatan keputrian diklasifikasikan menjadi 4: (1) keputerian; (2) pengembangan diri; (3) seni; dan (4) keterampilan. Vsi kegiatan keputerian adalah "membiasakan dan menanamkan keterampilan penataan pribadi, keluarga dalam kehidupan sehari-hari pada kompetensi kaum perempuan (kerajinan, keterampilan, tata boga, tata busana) untuk membangun karakter peserta didik yang inspiratif dan sportif'.

Kegiatan pembinaan peserta didik juga dilakukan melalui penyelenggaraan upacara bendera setiap hari Senin, kegiatan masa orientasi siswa (MOS), dan beberapa kegiatan pembinaan keimanan dan ketakwaan terhadap Tuhan YME. Kegiatan pembinaan keimanan dan ketakwaan yang diterapkan pada madrasah ini diantaranya adalah diwajibkannya sholat dzuhur/ashar berjamaah, pembiasaan sholat dhuha, mabid bagi peserta didik kelas IX yang akan menghadapi ujian nasional. 


\section{Strategi Pendidikan Karakter Secara Terpadu Melalui Manajemen Madrasah}

Sebagaimana proses manajamen pada umumnya, manajamen madrasah yang diterapkan pada MTs Muhammadiyah 01 Purbalingga meliputi proses perencanaan, pelaksanaan, dan pengendalian. Ketiga proses tersebut merupakan satu kesatuan yang tidak terpisahkan dalam pelaksanaan proses manajamen madrasah. Prinsip-prinsip dalam proses manajemen madrasah yang berkarakter secara umum sudah diterapkan, diantaranya adalah sebagai berikut.

1. Kejelasan tugas dan pertanggungjawaban

Pembagian tugas bagi tenaga pendidik maupun tenaga kependidikan yang dilakukan di MTs Muhammdiyah 01 Purbalingga diuraikan dengan jelas dan dipahami oleh masing-masing pemangku tugas. Pembagian tugas disesuaikan dengan kualifikasi yang dimiliki dengan harapan agar tugas yang diemban dapat terlaksana secara optimal.

2. Pembagian tugas berdasarkan asas the right man on the right place

Tenaga pendidik pada MTs Muhammadiyah 01 berjumlah 24 orang, yang berlatar belakang pendidikan S-1 berjumlah 23 orang $(95,8 \%)$ dan yang berlatar belakang pendidikan D-2 berjumlah 1 orang $(4,2 \%)$. Pembagian tugas bagi tenaga pendidik yang dilakukan di madrasah ini telah sesuai dengan kualifikasi dan kompetensi sesuai dengan mata pelajaran yang diampu. Kesesuaian antara tugas dengan kualifikasi yang dimiliki oleh pengemban tugas diharapkan mampu menumbuhkan komitmen yang tinggi bagi para pengemban tugas, sehingga tercapainya tujuan di masa depan akan lebih maksimal.
3. Teratur

Teratur yang merupakan salah satu prinsip manajemen madrasah yang berkarakter ini diterapkan dengan diberlakukannya peraturan yang mengikat semua warga madrasah. Peraturan bagi guru meskipun tidak dibuat secara tertulis, namun secara praktis telah dipatuhi dan dilaksanakan oleh seluruh guru. Sedangkan peraturan yang mengikat peserta didik dibuat secara tertulis untuk dipatuhi dab dijalani oleh peserta didik. Selain melalui peraturan dan tata tertib, prinsip teratur juga diterapkan melalui kegiatan pembiasaan diri, diantaranya adalah kegiatan sholat dzuhur/ashar berjamaah, sholat jumat, infak, dan kegiatan pembiasaan diri yang lain yang dijalani oleh guru dan peserta didik.

4. Disiplin

Prinsip disiplin diterapkan bagi seluruh guru, tanaga kependidikan, dan peserta didik dalam mentaati peraturan yang telah dibuat, khususnya dalam hal menghargai waktu. Selain itu, disiplin juga diwujudkan dengan memberikan sanksi terhadap pelanggaran yang dilakukan terhadap tata tertib madrasah. Sanksi yang diberikan didasarkan pada perhitungan poin pelanggaran sesuai dengan bobot yang telah ditentukan.

5. Adil (seimbang)

Prinsip keadilan mengarah pada terwujudnya keseimbangan antara hak dengan kewajiban, penghargaan dengan hasil karya, punishment dengan tingkat kesalahan, baik yang dilakukan oleh guru, staf tata usaha maupun para peserta didik dan warga sekolah lainnya. Implementasi prinsip adil sudah diterapkan oleh MTs Muhammadiyahdenganadanya pemberian penghargaan/reward bagi peserta didik yang meraih prestasi terkait dengan hasil belajar di kelas maupun prestasi yang 
diperoleh melalui ajang kompetisi antar sekolah/madrasah. Sedangkan punishment diberikan bagi peserta didik yang tidak patuh terhadap tata tertib yang berlaku di madrasah ini. Pemberian reward dan punishment masih terbatas pada peserta didik saja, sedangkan untuk guru dan tenaga kependidikan belum ada aturan yang dibuat terkait pemberian reward dan punishment.

\section{Semangat Kebersamaan}

Semangat kebersamaan merupakan modal sosial yang hendaknya dikembangkan di sekolah/madrasah. Prinsip semangat kebersamaan pada MTs Muhammadiyah 01 Purbalingga dikembangkan melalui kegiatan-kegiatan pembiasaan diri, diantaranya adalah dengan membezuk teman/guru/orang tua yang sakit, kegiatan takziyah, dimana dana yang digunakan bersumber dari infak dan iuran sukarela. Selain itu, semangat kebersamaan juga ditandai dengan sikap saling menghormati, baik antar guru, antar teman, maupun peserta didik dengan guru. Salah satu wujud sikap saling menghormati ditunjukan dengan saling mengucapkan salam dan cium tangan pada saat peserta didik bertemu dengan guru.

\section{Strategi Pendidikan Karakter Melalui Pembelajaran}

Strategi pendidikan karakter melalui pembelajaran yang diterapkan pada MTs Muhammadiyah 01 Purbalingga masih terbatas pada mata pelajaran tertentu saja, yaitu IPA, PKn, IPS, Quran Hadits, dan Aqidah Akhlak. Proses perencanaan pembelajaran dilakukan dengan menyusun silabus, RPP, dan bahan ajar yang didalamnya sudah memuat nilainilai karakter yang ingin dicapai. Silabus dan RPP disusun dengan menambahkan dan memodifikasi kegiatan pembelajaran sehingga terdapat kegiatan pembelajaran yang mengembangkan karakter.

Dalam pelaksanaan pembelajaran, pengembangan karakter dilakukan pada kegiatan pendahuluan, kegiatan inti, dan kegiatan penutup. Kegiatan pendahuluan yang dilakukan oleh guru misalnya dengan mengucapkan salam, mengecek daftar hadir, memberikan pertanyaan kepada peserta didik terkait dengan pelajaran yang lalu, dan memotivasi peserta didik. Kegiatan inti bermuatan karakter yang dilakukan di madrasah ini salah satunya dengan mengembangkan metode pembelajaran yang memotivasi peserta didik untuk dinamis dan bekerja keras. Berdasarkan hasil pengamatan pada pembelajaran PKn kelas VIII, salah satu metode yang digunakan dalam proses pembelajaran adalah metode pembelajaran koperatif. Penggunaan metode pembelajaran koperatif sangat sesuai dengan karakter pembelajaran kontekstual yang dianjurkan dalam rangka pengembangan pendidikan karakter dalam proses pembelajaran. Dengan menggunakan metode koperatif peserta didik termotivasi untuk lebih ingin tahu, aktif, dan bekerja keras untuk menyelesaikan masalah yang diberikan oleh guru. Kegiatan penutup dalam proses pembelajaran terkait dengan pengembangan karakter dilakukan dengan memberikan penilaian sebagai refleksi dari kegiatan pembelajaran yang telah dilakukan.

Evaluasi pencapaian hasil belajar yang diterapkan di madrasah ini masih didominasi pada penilaian tes yang mengukur aspek kognitif peserta didik. teknik penilaian yang digunakan adalah tes tertulis, tes lisan, dan penugasan individual maupun kelompok. Teknik penilaian lain seperti observasi, portofolio, jurnal, penilaian diri, dan penilaian antar teman belum diterapkan dalam rangak mengevaluasi pencapaian hasil belajar. 


\section{Strategi Pendidikan Karakter Melalui Pembinaan Peserta Didik}

Pendidikan karakter melalui kegiatan pembinaan sudah diterapkan di MTs Muhammadiyah 01 Purbalingga. Diantara kegiatan pembinaan yang eksis dan berkembang di madrasah ini adalah kegiatan ekstra kurikuler yang dilakukan di luar jam pelajaran. Kegiatan ekstra kurikuler yang paling diminati di madrasah ini adalah kegiatanseni bela diri Tapak Suci. Melalui kegiatan tapak suci ini dikembangkan nilai karakter disiplin, percaya diri, cinta tanah air, kerja keras, dan bergaya hidup sehat. Kegiatan ekstra kurikuler lainnya adalah kepramukaan, PMR, keputrian, TIK, dan olah raga yang masing-masing memiiki muatan nilai-nilai karakter bagi peserta didik.

Pendidikan karakter melalui pembinaan juga dilakukan dengan adanya kegiatan upacara bendera yang rutin dilaksanakan setiap hari Senin dan hari besar nasional. Melalui kegiatan upacara bendera diharapkan peserta didik dapat mengembangkan nilai karakter disiplin dan cinta terhadap tanah air. Dalam rangka meningkatkan kepercayaan dan ketakwaan kepada Allah swt, strategi pendidikan karakter dilakukan dengan menyelenggarakan kegiatan sholat dzuhur/ ashar berjamaah yang wajib bagi seluruh peserta didik dan guru, kegiatan sholat dhuha, dan kegiatan mabid bagi peserta didik kelas IX yang akan menghadapi ujian nasional.

\section{PENUTUP}

\section{Kesimpulan}

Pertama, strategi pendidikan karakter secara terpadu dalam manajemen madrasah sudah diterapkan di MTs Muhammadiyah 01 Purbalingga namun belum maksimal. Dalam penyusunan perencanaan belum tercantum secara eksplisit nilai-nilai karakter yang akan dicapai, baik melalui rencana kerja madrasah tahunan maupun rencana kerja madrasah jangka menengah (empat) tahunan. Namun dalam tataran praktis, madrasah ini sudah melakukan internalisasi nilai-nilai karakter melalui tata tertib beserta poin pelanggarannya dan melalui kegiatan pembiasaan diri.

Kedua, integrasi pendidikan karakter dalam pelaksanaan pembelajaran sudah nampak pada beberapa mata pelajaran diantarnya adalah pelajaran IPA, PKn, IPS, Quran Hadits, dan Aqidah Akhlak. Internalisasi nilai-nilai karakter diterapkan sejak proses perencanaan pembelajaran pelaksanaan pembelajaran, sampai pada proses evaluasi hasil belajar.

Ketiga, kegiatan pembinaan peserta didik dilakukan melalui beberapa kegiatan ekstrakurikuler, yaitu pramuka, PMR, tapak suci, olah raga, keputrian, dan TIK. Selain itu, pembentukan karakter juga dilakukan melalui kegiatan upacara bendera, MOS, dan kegiatankegiatan pembinaan keimanan dan ketakwaan kepada Allah swt, seperti kegiatan mabid bagi kelas IX, sholat dzuhur/ashar berjamaah, sholat dhuha, dan infak.

\section{Rekomendasi}

Berdasarkan hasil penelitian direkomendasikan kepada kepala madrasah untuk selalu berupaya meningkatkan wawasan terkait strategi pendidikan karakter pada madrasah baik bagi kepala madrasah sendiri maupun bagi seluruh guru. Kementerian Agama perlu memberikan sosialisasi tentang strategi pendidikan karakter pada madrasah melalui kegiatan seminar, diklat, dan workshop.

\section{SUMBER BACAAN}

Afrianti, Desy dan Siti Ruqoyah. 2012. 2.008 Kasus Kriminal Dilakukan Anak-anak. Diperoleh melalui http://metro.news.viva.co.id/ news/read/312779-2-008-kasus-kriminal -dilakukan-anak-anak. Diakses tanggal 22 April 2013

Alwisol. 2006. Psikologi Kepribadian. Malang: UMM. 
Arifin, Zainal. 2011. Evaluasi Pembelajaran: Prinsip, Teknik, Prosedur. Bandung: PT. Remaja Rosdakarya.

Fathurrohman, P., Suryana, AA, dan Fatriany, F. 2013. Pengembangan Pendidikan Karakter. Bandung: Refika Aditama.

Gomes, F. 2003. Manajemen Sumber Daya Manusia. Yogyakarta: Andi Offset.

Kementerian Pendidikan Nasional. 2010. Pendidikan Karakter Di Sekolah Menengah Pertama. Jakarta.

Lickona, T. 1991. Educating for Character: How Our School Can Teach Respect and Responsibility. New York, Toronto, London, Sydney, Aucland: Bantam books.

Marzuki. 2011. Integrasi Pendidikan Karakter dalam Pembelajaran di Sekolah Menengah Pertama. Makalah Seminar "Internalisasi Pendidikan Karakter Melalui Proses Pembelajaran dalam rangka Mewujudka“ Generasi yang Bernurani, Cendekia, da
Mandiri" yang diselenggarakan di SMP Negeri 5 Wates pada hari Senin, 25 Juli 2011.

Pusat Kurikulum dan Perbukuan Badan Penelitian dan Pengembangan Kementerian Pendidikan Nasional. 2011. Pedoman PelaksanaanPendidikan Karakter.Berdasarkan Pengalaman di Satuan Pendidikan Rintisan. Jakarta.

Sulistyowati, E. 2012. Implementasi Kurikulum Pendidikan Karakter. Yogyakarta: PT. Citra Aji Parama.

Usman, H. 2009. Manajemen. Teori, Praktik, dan Riset Pendidikan. Jakarta: Bumi Aksara. 